\section{Australian Journal of \\ Crop Science}

AJCS 14(10):1654-1661 (2020)

doi: 10.21475/ajcs.20.14.10.p2522
ISSN:1835-2707

\title{
Rhizobacterium Serratia sp. and phosphorus fertilization rates affect aerobic rice development
}

\author{
Adriano Stephan Nascente ${ }^{1 *}$, Marta Cristina Corsi de Filippi ${ }^{1}$, Thatyane Pereira de Sousa ${ }^{2}$, Amanda \\ Abdallah Chaibub ${ }^{3}$, Alan Carlos Alves de Souza ${ }^{4}$, and Anna Cristina Lanna ${ }^{1}$
}

\author{
${ }^{1}$ Brazilian Agricultural Research Corporation (EMBRAPA), Rice and Beans Research Center, P.O. Box 179, Highway \\ 462, km 12, Santo Antônio de Goiás, State of Goiás, 75.375-000, Brazil \\ ${ }^{2}$ Escola de Agronomia, Universidade Federal de Goiás, Goiânia - GO, Brazil \\ ${ }^{3}$ Departamento de Fitopatologia, Universidade de Brasília, Brasília - DF, Brazil \\ ${ }^{4}$ Departamento de Fitopatologia, Universidade Federal de Lavras, Lavras - MG, Brazil
}

\section{*Corresponding author: adriano.nascente@embrapa.br}

\begin{abstract}
Beneficial microorganisms participate in different processes that affect transformation of soil nutrients, including phosphorus (P), making them available for plants. However, there are few studies about the use of beneficial microorganism and P fertilization in the development of aerobic rice. The objective was to determine the effect of Serratia spp. isolate BRM 32114 and doses of P at sowing on the production of biomass, gas exchange, nutrient content in leaves and grain, grain yield and its components of aerobic rice. The field experiments were conducted over two growing seasons, 2015/16 and 2016/17, under a no-tillage system in the Brazilian Cerrado. The experimental design was a complete randomized block in a factorial $4 \times 2 \times 2$ scheme, with four replications. The treatments consisted of four $\mathrm{P}_{2} \mathrm{O}_{5}$ doses $\left(0,40,80\right.$ and $\left.120 \mathrm{~kg} \mathrm{ha}^{-1}\right)$ with or without rhizobacterium (2) in two growing seasons (2). Phosphorus rates increased the number of panicles and grain yield of aerobic rice, and the grain yield was higher in Serratia inoculation compared to no inoculation. The Serratia spp. strain BRM 32114 inserted in the production system of aerobic rice, under no-tillage, promoted gas exchange activity; enriched the $\mathrm{K}^{+}, \mathrm{Ca}^{+2}$ and $\mathrm{Mg}^{+2}$ content in leaves; enhanced biomass accumulation (13\%), and resulted in a higher number of panicles per plant (11\%) and grain yield (19\%) than untreated plants. Therefore, this beneficial microorganism is a promising technology for potential incorporation into cropping systems in Tropical regions of the world.
\end{abstract}

Keywords: bioagent, Oryza sativa, fertilization, growth promoter, rhizobacteria, sustainable development.

Abbreviations: GPR_growth promoting rizhobacteria; PGPM_plant growth promoting microorganisms; A_photosynthesis rate; E_transpiration rate: gs_stomatal conductance; $\mathrm{Ci}$ _internal $\mathrm{CO}_{2}$ concentration; Tleaf_leaf temperature; PPFD_photon flux density photosynthetic active.

\section{Introduction}

Rice is a staple food in many countries of the world (Kumar and Ladha, 2011). As the population is increasing, there is a need to increase rice grain yield to meet the people's demands. Average grain yields of aerobic rice are generally less than $2000 \mathrm{~kg} \mathrm{ha}^{-1}$ in most of the aerobic rice producing regions due to many environmental stresses and use of low inputs by farmers (Fageria and Baligar, 2003). However, aerobic rice is increasing worldwide as it is reducing the available water for irrigated rice (Kumar and Ladha, 2011).

The soil fertility of tropical regions, such as those found in the Brazilian Cerrado, African Savannas and Asia, is limited mainly by the low natural availability of phosphorus $(P)$ due to low nutrient contents in the forms available to plants or by high nutrient complexion rates, due to the chemical fixation reactions with soil particles (Fageria and Nascente, 2014). Almost 75 to $90 \%$ of added $P$ fertilizer in agricultural soils is sorption and precipitated by iron, aluminum and calcium complexes present in soils (Turan et al., 2006). Thus, cultivation systems require constant and relatively large amounts of $\mathrm{P}$ application to ensure the crops productivity. However, it also increases production costs. Several studies around the world have shown the positive effect of $P$ fertilization in growth, yield components, and grain yield of rice (Crusciol et al., 2005; Fageria et al., 2013; Nascente et al., 2014).

Although the economic benefits of phosphorus fertilization on crop production is well described, excessive soil phosphorus is a potential threat to water quality. Phosphorus lost from agricultural soils, together with nitrogen, are usually, the nutrients that controls eutrophication of fresh waters. Eutrophication permits algal blooms, fish kills, harm wildlife and livestock by causing anoxia, or through the production of toxins, difficulty of drinking water purification (Mullins, 2009).

Soil microorganisms considered plant growth promoting microorganisms (PGPM) participate in different processes that affect the transformation of soil nutrients and play an essential role on soil nutrients cycle (Chen et al., 2006), such 
as solubilizing unavailable soil $P$ into soluble forms (Viverk and Singh, 2001; Sudhakara et al., 2002).

Among the bacterial genera with this capacity are Achromobacter, Aereobacter Agrobacterium, Azotobacter Bacillus ssp, Bacillus circulans, Bradyrhizobium, Burkholderia, Enterobacter, Erwinia, Flavobacterium, Kushneria, Microccocus, Paenibacillus, Pseudomonas, Ralstonia, Rhizobium, Rhodococcus, Salmonella, Serratia, Sinomonas and Thiobacillus (Alori et al., 2017; Goldstein, 1986; Krishanaraj and Goldstein, 2001; Rodriguez and Fraga, 1999). Besides, previous studies showed that Serratia ssp, strain BRM 32114 promoted an increase in gas exchange, nutrients accumulation and biomass production, which differed from the control (untreated plants) in the aerobic rice plants, in greenhouse conditions (Nascente et al., 2017).

There are still few studies under field conditions for the use of rizhobacteria in crop development, especially in rainfed places and fewer in the Cerrado region. Therefore, the objective was to determine the effect of the Serratia spp. isolated BRM32114 and doses of P at sowing fertilization on the production of biomass, gas exchange, nutrient content in leaves and grain yield components and grain yield of aerobic rice, under a no-tillage system in a Cerrado Region.

\section{Results}

\section{Leaf gas exchange evaluation}

The presence of Serratia spp. strain BRM32114 provided changes in the gas exchange parameters in aerobic rice plants. However, there was no difference of these parameters among $\mathrm{P}$ rates (Table 2). For gs, there was interaction between Serratia spp. strain BRM32114 and evaluation time and between Serratia spp. strain BRM 32114 and growing season. Hence, the plants showed greater ability to perform gas exchange in the early stages of their development, mainly in growing season 2016/17 (Table 3). For $\mathrm{A}, \mathrm{E}, \mathrm{Ci}$ and Tleaf, there was interaction between evaluation time and growing season. Aerobic rice plants in reproductive stage presented higher values of $A, E$ and Tleaf in 2015/16; while, A and Tleaf values were higher in plants, at the vegetative stage, in 2016/17. Ci presented a significant difference only in the 2015/16 crop, and higher values were obtained in plants at the vegetative stage. The interaction between Serratia spp. strain BRM32114 and growing season showed that at the growing season 2015/16, treated plants presented higher $\mathrm{E}, \mathrm{Ci}$ and Tleaf, and untreated plants presented higher $\mathrm{Ci}$. In the growing season 2016/17, treated plants presented increase in gs and $\mathrm{Ci}$ parameters. Tleaf was higher in untreated plants.

\section{Nutrient content in rice leaves}

The treatments with Serratia spp. strain BRM32114 positively affected $\mathrm{K}, \mathrm{Ca}$ and $\mathrm{Mg}$ content in rice leaves (Table 4), and did not affect $\mathrm{N}, \mathrm{P}, \mathrm{Cu}, \mathrm{Fe}, \mathrm{Mn}$ and $\mathrm{Zn}$ content. Considering treated and untreated plants together, in growing season 2015/2016 rice leaves presented higher values of $\mathrm{P}, \mathrm{K}, \mathrm{Mg}, \mathrm{Fe}$ and $\mathrm{Zn}$. In the growing season 2016/17, rice leaves presented higher values of $\mathrm{N}, \mathrm{Ca}, \mathrm{Cu}$ and $\mathrm{Mn}$. There was no effect of $\mathrm{P}$ rates in the nutrient content in rice leaves.
Plant biomass, yield components and grain yield of aerobicrice plants

The use of Serratia spp. strain BRM32114 provided increases in plant biomass, number of panicle per plant and grain yield of aerobic rice (Table 5). Number of grains per panicle and mass of 1000 grains was not affected by Rhizobacterium treatment.

Regarding growing season effect, in 2016/17, plants presented higher biomass, number of panicle per plant, number of grains per panicle and grain yield than growing season 2015/2016 (Table 5). There was no effect of $P$ rates in the plant biomass, number of grains per panicle and mass of 1000 grains. On the other hand, there was an effect of $P$ rate on the number of panicles (Fig 2) and an interaction between Serratia spp. strain BRM32114 and P rate for grain yield (Fig 3).

\section{Nutrient content in rice grains}

Plants not treated with Serratia spp. had a higher N, Cu and $\mathrm{Zn}$ content in rice grains (Table 6). In growing season $2015 / 16$, the contents of $\mathrm{P}, \mathrm{K}, \mathrm{Mg}, \mathrm{Cu}$ and $\mathrm{Mn}$ were higher.

\section{Discussion}

One of the environmental conditions that could positively affect the grain yield is the rain distribution (Heinemann and Stone, 2009). Total rainfall for the growing season 2015/2016 (692.8 $\mathrm{mm}$ ) was higher than growing season 2016/2017 (678.2 mm). However, it was not equally distributed. There was less rain in the period from flowering to grain filling in the growing season 2015/2016 (195.4 mm) than in the growing season 2016/2017 (370.0 mm) (Fig 1). Associated with rainfall distribution, the greater soil fertility at 2016/17 (Table 1) could explain the higher rice grain yield in this season and other differences between these seasons. However, independent of rain and fertility conditions, there were an increase in plant biomass (13\%), number of panicle per plant (11\%) and grain yield (19\%), in Serratia spp. strain BRM 32114-treated aerobic rice plants. The observed gain seems to be determined by $A$ (photosynthetic rate) and gs (stomatal conductance), which was increased by 6 and $28 \%$, respectively, in treated plants. The treatment with Serratia spp. strain BRM 32114 affected gs more than A in aerobic rice plants, indicating that the gas exchange capability was potentiated in treated plants. The processes of grain and biomass production depends on the sink size, pre-anthesis dry matter, translocation of pre-anthesis assimilates to grain, nutrient accumulated and remobilized as well as assimilate source (light capture and photosynthetic rate) (Alvarez et al., 2014; Sandhu et al., 2015). Augé (2001), Bandara et al. (2006), Guo et al. (2008), Pérez-García et al. (2011), Barzana et al. (2012) and Nascente et al. (2017) have also shown that microorganisms can provide indirect stimulation in crop plants by promoting greater gas exchange activity. Regarding the nutritional status of the plants, it was observed that Serratia spp. strain BRM 32114 significantly increased the $\mathrm{K}, \mathrm{Ca}$ and $\mathrm{Mg}$ content in rice leaves over the average of two growing seasons. Microorganisms can also provide indirect plant growth stimulation by improving the availability and absorption of nutrients (Pérez-García et al., 2011; Zhang et al., 2011). One of the hypotheses is that beneficial microorganisms modify 
Table 1. Chemical and physical properties of the soil at the beginning of the trial.

\begin{tabular}{|c|c|c|c|c|c|c|c|}
\hline \multicolumn{8}{|c|}{ Jrowing season $2015 / 2016$} \\
\hline Depth & $\mathrm{Ca}$ & $\mathrm{Mg}$ & $\mathrm{H}+\mathrm{Al}$ & $\mathrm{SOM}^{1}$ & $P$ & K & $\mathrm{pH}\left(\mathrm{H}_{2} \mathrm{O}\right)$ \\
\hline (m) & \multicolumn{3}{|c|}{---- $\mathrm{mmol}_{\mathrm{c}} \mathrm{dm}^{-3}$} & $\mathrm{~g} \mathrm{dm}^{-3}$ & \multicolumn{2}{|c|}{$----m g d m^{-3}---$} & \\
\hline $0-0.20$ & 18.0 & 13.3 & 24.0 & 32.7 & 9.9 & 101.3 & 5.9 \\
\hline $\begin{array}{l}\text { Depth } \\
\text { (m) }\end{array}$ & \multicolumn{4}{|c|}{ 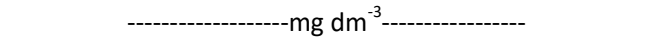 } & Clay & $\begin{array}{r}\text { Silt } \\
--g ~ k g\end{array}$ & Sand \\
\hline $0-0.20$ & 0.8 & 4.6 & 20.5 & 10.1 & 480 & 226 & 294 \\
\hline \multicolumn{8}{|c|}{ J̈rowing season $2016 / 2017$} \\
\hline Depth & $\mathrm{Ca}$ & $\mathrm{Mg}$ & $\mathrm{H}+\mathrm{Al}$ & $\mathrm{SOM}^{1}$ & $P$ & $\mathrm{~K}$ & $\mathrm{pH}\left(\mathrm{H}_{2} \mathrm{O}\right)$ \\
\hline (m) & \multicolumn{3}{|c|}{ - $\mathrm{mmol}_{\mathrm{c}} \mathrm{dm}^{-3}$} & $\mathrm{~g} \mathrm{dm}^{-3}$ & \multicolumn{2}{|c|}{----mg dm ${ }^{-3}---$} & \\
\hline $0-0.20$ & 10.7 & 10.9 & 31.0 & 42.22 & 12.6 & 97 & 5.5 \\
\hline $\begin{array}{l}\text { Depth } \\
\text { (m) }\end{array}$ & $\mathrm{Cu}$ & $\mathrm{Zn}$ & $\mathrm{Fe}$ & $\mathrm{Mn}$ & Clay & $\begin{array}{r}\text { Silt } \\
--\mathrm{g} \mathrm{kg}\end{array}$ & Sand \\
\hline $0-0.20$ & 1.2 & 8.1 & 31.0 & 12.2 & 520 & 180 & 300 \\
\hline
\end{tabular}

${ }^{1} \mathrm{SOM}$ - soil organic matter.

Table 2. Phosphorus rates and Serratia spp. isolated BRM 321145 with or without inoculation in rice seeds as affecting photosynthesis (A), transpiration (E), stomatal conductance (gs), internal $\mathrm{CO}_{2}$ concentration (Ci) and leaf temperature (Tleaf) of rice plants in two growth stages at vegetative and reproductive phase of rice development. Santo Antônio de Goiás, growing season 2015/2016 and 2016/2017.

\begin{tabular}{|c|c|c|c|c|c|}
\hline Factors & A & $E$ & gs & $\mathrm{Ci}$ & Tleaf \\
\hline Serratia BRM32114 & $\mu \mathrm{mol} \mathrm{CO}{ }_{2} \mathrm{~m}^{-2} \mathrm{~s}^{-1}$ & $\mathrm{mmol} \mathrm{H}_{2} \mathrm{O} \mathrm{m}^{-2} \mathrm{~s}^{-1}$ & $\mathrm{~mol} \mathrm{H}_{2} \mathrm{O} \mathrm{m}^{-2} \mathrm{~s}^{-1}$ & vpm & $\stackrel{\circ}{ } \mathrm{C}$ \\
\hline With & $25.67 a^{*}$ & 6.00 & $1.27 \mathrm{a}$ & 287 & 29.92 \\
\hline Without & $24.21 \mathrm{~b}$ & 5.95 & $0.99 \mathrm{~b}$ & 284 & 29.83 \\
\hline \multicolumn{6}{|l|}{ Growth stage } \\
\hline Vegetative & $26.37 \mathrm{a}$ & 6.03 & 1.19 & 295 a & $29.01 \mathrm{~b}$ \\
\hline Reproductive & $23.50 \mathrm{~b}$ & 5.91 & 1.06 & $276 b$ & $30.74 \mathrm{a}$ \\
\hline \multicolumn{6}{|l|}{ Growing season } \\
\hline $2015 / 2016$ & $23.32 b$ & 6.01 & $0.51 \mathrm{~b}$ & $256 \mathrm{~b}$ & $31.89 \mathrm{a}$ \\
\hline $2016 / 2017$ & $26.55 \mathrm{a}$ & 5.94 & $1.75 \mathrm{a}$ & 315 a & $27.86 \mathrm{~b}$ \\
\hline Factors & \multicolumn{5}{|c|}{ ANOVA (F Probability) } \\
\hline$\overline{\text { Serratia }(\mathrm{S})}$ & $<0.001$ & 0.7231 & 0.0119 & 0.2817 & 0.6771 \\
\hline Phosphorus rates $(P)$ & 0.0507 & 0.4303 & 0.9025 & 0.6709 & 0.9957 \\
\hline Growth stage (GSt) & $<0.001$ & 0.4438 & 0.2410 & $<0.001$ & $<0.001$ \\
\hline Growing season (GS) & $<0.001$ & 0.6603 & $<0.001$ & $<0.001$ & $<0.001$ \\
\hline$S \times P$ & 0.0525 & 0.4491 & 0.7360 & 0.6456 & 0.9947 \\
\hline S x GSt & 0.8448 & 0.9490 & 0.0088 & 0.8498 & 0.5926 \\
\hline$S \times G S$ & 0.4044 & 0.0302 & 0.0215 & 0.0002 & 0.0060 \\
\hline P x GSt & 0.0501 & 0.9505 & 0.1322 & 0.9284 & 0.9433 \\
\hline$P \times G S$ & 0.0612 & 0.8398 & 0.8200 & 0.7570 & 0.9099 \\
\hline GSt $\times$ GS & $<0.001$ & $<0.001$ & 0.1263 & $<0.001$ & 0.0094 \\
\hline$S \times P \times G S t$ & 0.5577 & 0.3154 & 0.8288 & 0.9252 & 0.9828 \\
\hline$S \times P \times G S$ & 0.0519 & 0.3703 & 0.7344 & 0.4490 & 0.9491 \\
\hline$P \times G S t \times G S$ & 0.7864 & 0.5527 & 0.1973 & 0.5308 & 0.9842 \\
\hline S x GSt $x$ GS & 0.0761 & 0.3444 & 0.0519 & 0.3578 & 0.3313 \\
\hline$S \times G S t \times G S \times P$ & 0.0524 & 0.5490 & 0.8342 & 0.6235 & 0.9858 \\
\hline
\end{tabular}

*Means followed by the same letter do not differ by Tukey's test $(\mathrm{P}<0.05)$.

Table 3. Interaction between growing season and growth stage for photosynthesis (A), transpiration (E), internal $\mathrm{CO}_{2} \mathrm{Concentration}(\mathrm{Ci})$ and leaf temperature (Tleaf) of rice plants at vegetative and reproductive phase of rice development, and with or without the use of rhizobacterium Serratia spp. strain BRM32114 with transpiration, stomatal conductance (gs), internal $\mathrm{CO}_{2}$ concentration and leaf temperature of aerobic rice plants. Santo Antônio de Goiás, growing season 2015/16 and 2016/17.

Interaction between growing season and growth stage

Growing season 2015/16

\begin{tabular}{|c|c|c|c|c|}
\hline Growth stage & $\mu \mathrm{mol} \mathrm{CO}_{2} \mathrm{~m}^{-2} \mathrm{~s}^{-1}$ & $\begin{array}{c}\mathrm{E} \\
\mathrm{mmol} \mathrm{H} \mathrm{H}_{2} \mathrm{~m}^{-2} \mathrm{~s}^{-1}\end{array}$ & $\begin{array}{c}\mathrm{Ci} \\
\mathrm{vpm}\end{array}$ & $\begin{array}{c}\text { Tleaf } \\
\text { oc }\end{array}$ \\
\hline Vegetative & 22.79 & $5.64 \mathrm{~b}^{*}$ & $272 \mathrm{a}$ & $30.71 b$ \\
\hline Reproductive & 23.86 & $6.38 \mathrm{a}$ & $239 \mathrm{~b}$ & $33.06 \mathrm{a}$ \\
\hline \multicolumn{5}{|c|}{ Growing season $2016 / 2017$} \\
\hline \multicolumn{5}{|l|}{ Growth stage } \\
\hline Vegetative & $29.96 \mathrm{a}$ & $6.43 a$ & 318 & $27.30 \mathrm{~b}$ \\
\hline Reproductive & $23.15 b$ & $5.45 \mathrm{~b}$ & 313 & $28.43 \mathrm{a}$ \\
\hline \multicolumn{5}{|c|}{ Interaction between growing season and rhizobacterium BRM32114 } \\
\hline \multicolumn{5}{|c|}{ Growing season $2015 / 16$} \\
\hline rhizobacterium & $\begin{array}{c}\mathrm{E} \\
\mathrm{mmol} \mathrm{H}_{2} \mathrm{O} \mathrm{m}^{-2} \mathrm{~s}^{-1}\end{array}$ & $\begin{array}{c}\text { gs } \\
\mathrm{mol} \mathrm{H}_{2} \mathrm{O} \mathrm{m}^{-2} \mathrm{~s}^{-1}\end{array}$ & $\begin{array}{c}\mathrm{Ci} \\
\mathrm{vpm}\end{array}$ & $\begin{array}{l}\text { Tleaf } \\
\text { oc }\end{array}$ \\
\hline With & $6.21 \mathrm{a}$ & 0.52 & $250 \mathrm{~b}$ & $32.26 \mathrm{a}$ \\
\hline Whitout & $5.81 \mathrm{~b}$ & 0.49 & $261 \mathrm{a}$ & $31.52 b$ \\
\hline \multicolumn{5}{|c|}{ Growing season $2016 / 17$} \\
\hline \multicolumn{5}{|l|}{ rhizobacterium } \\
\hline With & 5.79 & $2.02 \mathrm{a}$ & $324 a$ & $27.59 \mathrm{~b}$ \\
\hline Whitout & 6.08 & $1.48 \mathrm{~b}$ & $307 \mathrm{~b}$ & $28.14 \mathrm{a}$ \\
\hline
\end{tabular}

\footnotetext{
* Means followed by the same letter do not differ by Tukey's test $(\mathrm{P}<0.05)$
} 


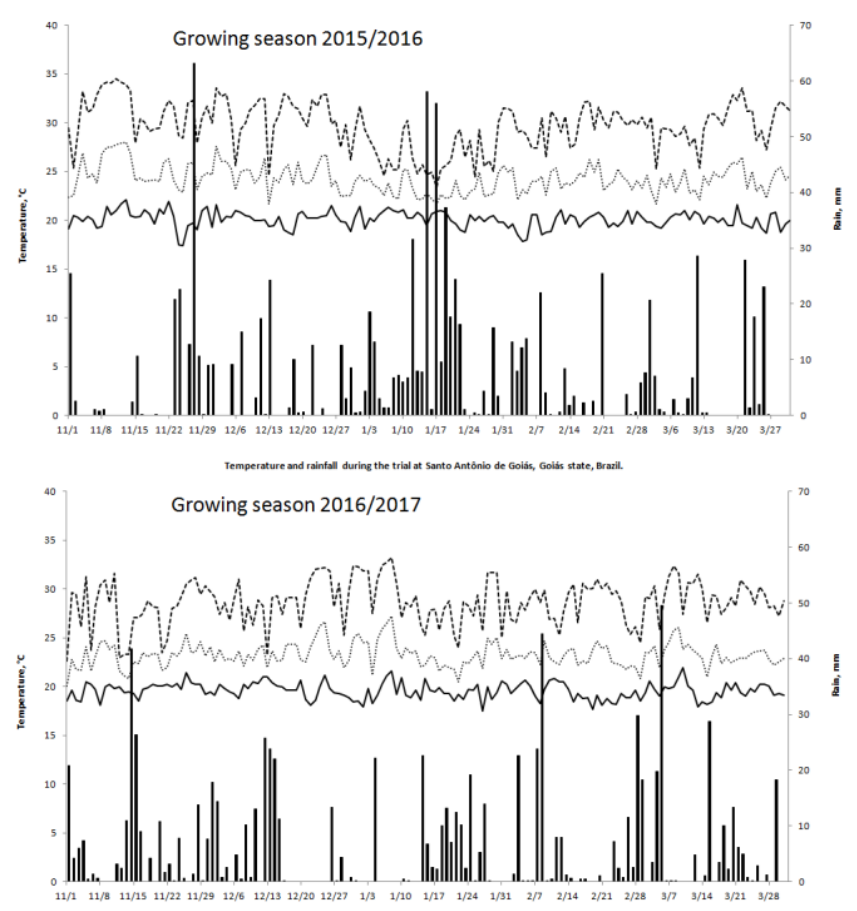

Fig 1. Maximum ( $T$ maximum), minimum ( $T$ minimum) and average ( $T$ average) temperatures and rainfall during the trial period of aerobicrice grown under a no-tillage system in the experimental fields of Santo Antônio de Goiás in the 2015/16 and 2016/17 growing seasons.

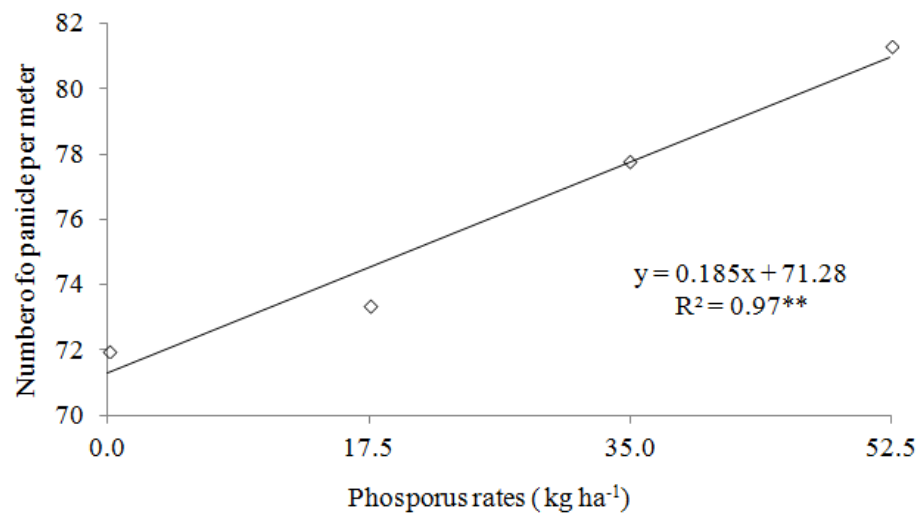

Fig 2. Number of panicles per meter of aerobic rice as a function of phosphorus rates. Average of growing seasons 2015/16 and 2016/17.

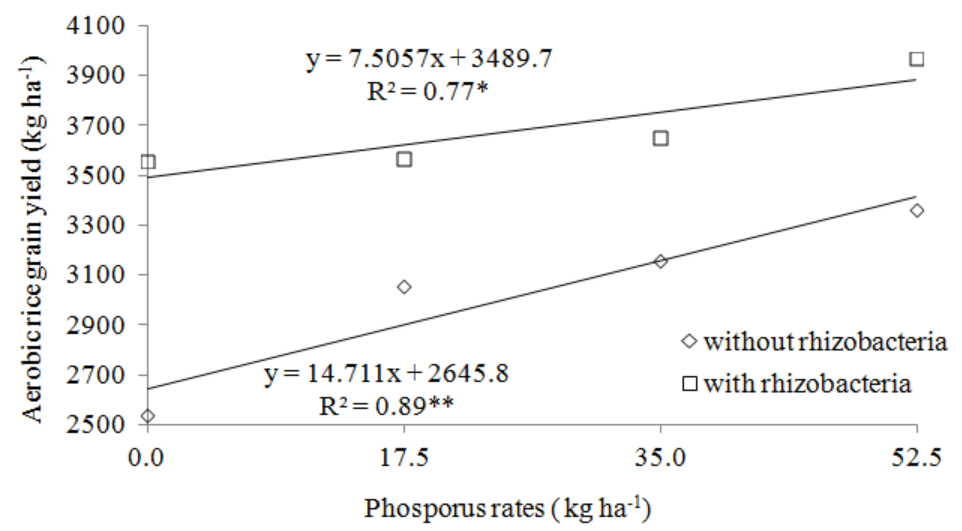

Fig 3. Aerobic rice grain yield as affected by use of Rhizobacteria BRM 32114and phosphorus rates. Average of growing seasons 2015/16 and 2016/17. 
Table 4. Phosphorus rates and Serratia spp. isolated BRM 32114 with or without inoculation in rice seeds as affecting nutrient content in rice leaves at full flowering stage. Santo Antônio de Goiás, growing season 2015/2016 and 2016/2017.

\begin{tabular}{|c|c|c|c|c|c|c|c|c|c|}
\hline Factors & $\mathrm{N}$ & $\mathrm{P}$ & $\mathrm{K}$ & $\mathrm{Ca}$ & $\mathrm{Mg}$ & $\mathrm{Cu}$ & $\mathrm{Fe}$ & $\mathrm{Mn}$ & $\mathrm{Zn}$ \\
\hline Serratia BRM32114 & \multicolumn{4}{|c|}{----------------------g kg } & \multicolumn{5}{|c|}{--------------'mg kg'-1------------ } \\
\hline With & 21.37 & 2.79 & $16.34 a^{*}$ & $3.26 \mathrm{a}$ & $2.21 \mathrm{a}$ & 6.60 & 112.18 & 69.85 & 35.55 \\
\hline Without & 21.16 & 2.92 & $15.76 \mathrm{~b}$ & $2.94 \mathrm{~b}$ & $2.04 \mathrm{~b}$ & 6.63 & 114.67 & 66.44 & 33.63 \\
\hline \multicolumn{10}{|l|}{ Growing season } \\
\hline $2015 / 2016$ & $12.70 \mathrm{~b}$ & $3.83 \mathrm{a}$ & $17.59 \mathrm{a}$ & $1.93 \mathrm{~b}$ & $2.39 \mathrm{a}$ & $6.23 \mathrm{~b}$ & 169 a & $34.76 b$ & $53.17 \mathrm{a}$ \\
\hline $2016 / 2017$ & 29.83 a & $1.89 \mathrm{~b}$ & $14.51 \mathrm{~b}$ & $4.27 \mathrm{a}$ & $1.88 \mathrm{~b}$ & $7.00 \mathrm{a}$ & $58 b$ & $101.53 \mathrm{a}$ & $16.01 \mathrm{~b}$ \\
\hline Factors & \multicolumn{9}{|c|}{ ANOVA (F probability) } \\
\hline 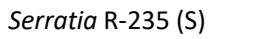 & 0.5849 & 0.3254 & 0.0437 & 0.0009 & 0.0003 & 0.8520 & 0.8098 & 0.4886 & 0.4106 \\
\hline Phosphorus rates $(\mathrm{P})$ & 0.9517 & 0.4819 & 0.5376 & 0.9587 & 0.6306 & 0.2404 & 0.9755 & 0.7641 & 0.2331 \\
\hline Growing season (GS) & $<0.001$ & $<0.001$ & $<0.001$ & $<0.001$ & $<0.001$ & 0.0002 & $<0.001$ & $<0.001$ & $=0.001$ \\
\hline$S \times P$ & 0.5304 & 0.8213 & 0.2014 & 0.2360 & 0.6979 & 0.3183 & 0.2685 & 0.6367 & 0.8397 \\
\hline$S \times G S$ & 0.9760 & 0.2337 & 0.2724 & 0.0502 & 0.0512 & 0.4969 & 0.3562 & 0.2118 & J.1930 \\
\hline$P \times G S$ & 0.1187 & 0.6462 & 0.0602 & 0.4440 & 0.2132 & 0.1941 & 0.2043 & 0.6169 & 0.2899 \\
\hline$S \times P \times G S$ & 0.5591 & 0.8884 & 0.5305 & 0.7785 & 0.8065 & 0.5830 & 0.5731 & 0.5823 & 0.8851 \\
\hline
\end{tabular}

* Means followed by the same letter do not differ by Tukey's test $(\mathrm{P}<0.05)$.

Table 5. Phosphorus rates and Serratia spp. isolated BRM 32114 with or without inoculation in rice seeds as affecting plant biomass (PB), number of panicles per plant (NPP), number of grain per panicle (NGP), mass of 1000 grains (1000M) and grain yield (GY) of aerobic rice. Santo Antônio de Goiás, growing season 2015/2016 and 2016/2017.

\begin{tabular}{|c|c|c|c|c|c|}
\hline Factors & PB & NPP & NGP & $1000 \mathrm{M}$ & GY \\
\hline Serratia BRM32114 & $\mathrm{g} \mathrm{m}^{-2}$ & unit & unit & $\mathrm{g}$ & $\mathrm{kg} \mathrm{ha}^{-1}$ \\
\hline With & $197 a^{*}$ & $80 \mathrm{a}$ & 134 & 23.63 & $3691 \mathrm{a}$ \\
\hline Without & $172 b$ & $72 b$ & 132 & 23.20 & $2990 \mathrm{~b}$ \\
\hline \multicolumn{6}{|l|}{ Growing season } \\
\hline $2015 / 2016$ & $143 \mathrm{~b}$ & $69 \mathrm{~b}$ & $122 \mathrm{~b}$ & 23.22 & $2303 b$ \\
\hline $2016 / 2017$ & $225 \mathrm{a}$ & $83 \mathrm{a}$ & $145 \mathrm{a}$ & 23.60 & $4379 \mathrm{a}$ \\
\hline Factors & \multicolumn{5}{|c|}{ ANOVA (F probability) } \\
\hline 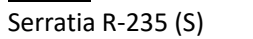 & 0.0088 & 0.0071 & 0.6236 & 0.1648 & $<0.001$ \\
\hline Phosphorus rates $(\mathrm{P})$ & 0.5371 & 0.0419 & 0.8639 & 0.3415 & 0.0428 \\
\hline Growing season (GS) & $<0.001$ & $<0.001$ & $<0.001$ & 0.2086 & $<0.001$ \\
\hline$S \times P$ & 0.6112 & 0.9475 & 0.4431 & 0.7248 & 0.0306 \\
\hline$S \times G S$ & 0.2474 & 0.9656 & 0.9519 & 0.1760 & 0.0965 \\
\hline$P \times G S$ & 0.7354 & 0.2527 & 0.1028 & 0.7550 & 0.3651 \\
\hline$S \times P \times G S$ & 0.9850 & 0.8306 & 0.611 & 0.8669 & 0.5976 \\
\hline
\end{tabular}

Table 6. Nutrient content in rice grains affected by phosphorus rates and Serratia spp. isolated BRM 32114 with or without inoculation in rice seeds during the growing season 2015/2016 and 2016/2017.

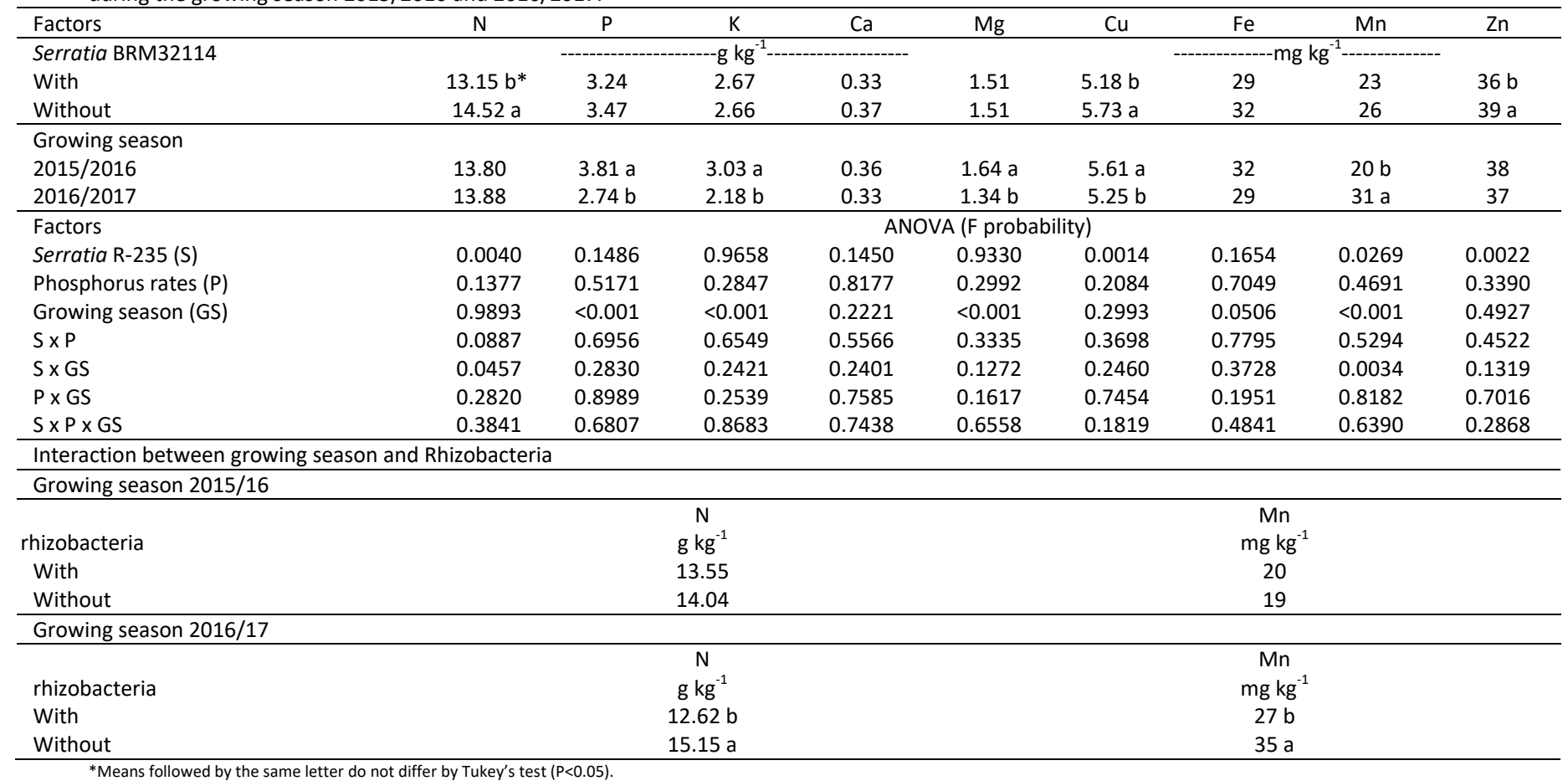


the structure of rice root (Rêgo et al., 2014). According to the authors, rice seeds treated with T. asperellum pool, Burkholderia sp. and Pseudomonas sp. showed changes in root architecture by increasing the length and the volume of the root. Both greater activity in gas exchange and nutrient enrichment in aerobic rice leaves are factors that most contributed to the greater accumulation of biomass in aerobic rice plants and number of panicle per plant, which had a significant effect on crop grain yield (Fageria et al., 2011).

Phosphorus rates provided increases in number of panicles and grain yield. Increasing rates of $P$, provided increases in the number of panicles and in grain yield. Several studies around the world have shown the positive effect of $P$ fertilization in growth, yield components, and grain yield of rice (Crusciol et al., 2005; Fageria et al., 2013a; Nascente et al., 2014). This could be due to the levels of $P$ in the soil (Table 1). However, the low response of nutrients to increase $P$ may be due to the adequate level in 2015/16 and high level in 2016/17 (Sousa and Lobato, 2003). The number of panicle per plant was higher in treated plants (Table 5 , Figure 3). It seems that the number of formed and fertile tillers made the difference. The beginning of tiller phase, when rice plants emits the $3^{\text {rd }}$ leaves does not depend on the environmental conditions. However, the emergence and development until 65 to 70 days, depend on nutritional and temperature conditions. To achieve vigorous tillering, $\mathrm{N}, \mathrm{P}$ and $\mathrm{S}$ are necessary, together with carbohydrate (Fageria 1984). According to our data (Fig 2), there is a positive influence of different $P$ rates on tillage numbers $\mathrm{m}^{-2}$, until 60 days after sowing (Fageria et al., 1982). BRM 32114 is an Indoleacetic acid (IAA) and phosphatase producer (Nascente et al., 2017), which may enhance the tillering successful ensuring a higher number of fertile tillers and formed panicles (Fig 2 and Fig 3). Our results showed that using rhizobacterium Serratia spp. strain BRM 32114 with phosphorus allowed more increase in grain yield than using only $\mathrm{P}$ rates. In this sense, it is likely that the rhizobacterium BRM32114 positively interacted with $\mathrm{P}$ fertilization.

Our research seems promising and showed that using a beneficial microorganism could bring many benefits to the crops systems. In this sense, using aerobic rice treated with beneficial microorganism could contribute to improve the profitability of the crop for the farmers. The adequate to high level of $P$ in the soil, along with rhizobacteria seem to improve the plant capacity to uptake nutrients to the plants and allowed higher grain yield than without rhizobacterium. The use of microbial for integrated nutrient management for rice production could contribute to a sustainable agriculture (Lavakush et al., 2014). Besides, our research confirmed the improvement of aerobic rice plants development allowed by the rhizobacterium under greenhouse condition (Nascente et al., 2017) in the field conditions.

\section{Materials and methods}

\section{Site description}

The experiments were conducted at Capivara Experimental Station of Embrapa Rice and Beans, located at Santo Antônio de Goiás, GO, Brazil, 1628'00"S and 4917'00"W coordinates, and at $823 \mathrm{~m}$ of elevation. The climate is Tropical Savanna and is considered Aw (tropical with wet summer and dry winter) according to Köppen classification (Köppen, 1918). Therefore, there are two well-defined seasons: a usually dry season from May to September (autumn/winter) and a wet season from October to April (spring/summer). The average annual rainfall is between 1500 and $1700 \mathrm{~mm}$, and the average annual temperature is $22.7^{\circ} \mathrm{C}$, ranging annually from $14.2^{\circ} \mathrm{C}$ to $34.8^{\circ} \mathrm{C}$. During the period of this study, the temperature and the amount of rainfall data were recorded (Fig 1).

The experimental soil is classified as a clay loam (kaolinitic, thermic Typic Haplorthox) acidic soil (Embrapa, 2006). Prior to the study, in November 2015 and 2016, chemical and physical analyses were performed according to the methodology by Donagema et al. (2011) for the initial characterization of the area (Table 1 ). Therefore, $\mathrm{P}$ and $\mathrm{K}$ were extracted by Mehlich 1 extracting solution (0.05M HC1 in $0.0125 \mathrm{M} \mathrm{H}_{2} \mathrm{SO}_{4}$ ). From the extracted, phosphorus content was determined colorimetrically and $\mathrm{K}$ by flame photometry. $\mathrm{Ca}, \mathrm{Mg}$, and $\mathrm{Al}$ were extracted with $1 \mathrm{M} \mathrm{KC1}$. Aluminum was determined by titration with $\mathrm{NaOH}$ and $\mathrm{Ca}$ and $\mathrm{Mg}$ by titration with EDTA from the extracted solution. Micronutrients were determined in a portion of the extract for $\mathrm{P}$ by atomic absorption spectrophotometry. Soil organic matter was determined by Walkley and Black's method.

\section{Experimental design and treatments}

Trials were conducted in rainfed conditions using the rice genotype Primavera CL. Trials were arranged in a complete randomized block in a $4 \times 2 \times 2$ factorial scheme, with four replications in different areas very close to each other. The plots had the dimension of $3.5 \mathrm{~m} \times 6 \mathrm{~m}$. The usable area of the plot (place where we sampled the data) was composed of the four central rows of rice, disregarding one row of each side of the plot and $0.50 \mathrm{~m}$ to each side of the rows in each plot. The treatments consisted of four $\mathrm{P}_{2} \mathrm{O}_{5}$ doses $(0,40,80$ and $120 \mathrm{~kg} \mathrm{ha}^{-1}$ as triple superphosphate) with or without Serratia spp in two growing seasons (2015/16 and 2016/17). The strain BRM32114 was applied by seed microbiolization and sprayed at plant/soil in the field at the 7 and 15 DAS (days after sowing) in all plots with rhizobacteria treatment. In the plots with no microorganisms, we applied only water. Serratia spp. strain BRM32114 belongs to the Microorganism Culture Collection at the Embrapa Rice and Bean Research Center, with KX378746 GenBank code.

\section{Seed microbiolization and plant/soil spray pulverization}

Serratia spp. strain BRM32114 bacterial suspensions were prepared with water, from cultures that had been growing for a 24 hour period on solid medium 523 (Kado and Heskett, 1970), at $28^{\circ} \mathrm{C}$, and the concentration was set in a spectrophotometer to $\mathrm{A} 540=0.5\left(10^{8} \mathrm{CFU}\right)$. Rice seeds were immersed in the bacterial suspension, during 24 hours under constant agitation at $25^{\circ} \mathrm{C}$, and control seeds (no bacteria) were immersed only in water, during 24 hours, in the same conditions. We performed plan (7 days after sowing) and soil (15 days after sowing) pulverization with bacterial suspension prepared as described above, in the same concentration $\left(10^{8} \mathrm{CFU} \mathrm{ml}^{-1}\right)$, at $600 \mathrm{I} \mathrm{ha}^{-1}$, with a costal atomizer.

\section{Rice crop management}

Cover crops were desiccated with a glyphosate application (1.8 $\mathrm{kg} \mathrm{ha}^{-1}$ acid equivalent) 30 days before sowing of the aerobic rice. The sowing was performed mechanically using 
200 seeds per $\mathrm{m}^{-2}$ of rice. The seeds were sown on December $15^{\text {th }}, 2015$ and on November $23^{\text {rd }}, 2016$. Seven days before the sowing of the rice, the seed microbiolization was carried out. Rice plant emergence occurred five days after sowing for both growing seasons. The base fertilization, to be applied in the sowing furrows, was calculated according to the soil's chemical characteristics and followed the recommendations of Sousa and Lobato (2003). Therefore, sowing fertilization was $\mathrm{P}$ rates according each treatment and $50 \mathrm{~kg} \mathrm{ha}^{-1}$ of $\mathrm{N}$ as urea. Topdressing fertilization was performed 18 days after sowing with $45 \mathrm{~kg}$ $\mathrm{ha}^{-1}$ of $\mathrm{N}$ as urea, in both years. Cultural practices were performed according to standard recommendations for a rice crop to keep the area free from weeds, diseases and insects.

\section{Evaluations of traits}

\section{Leaf gas exchange and photosynthetic capacity}

Aerobic rice gas exchange, at 37 and 68 days after emergence (DAE) for the first growing season (2015/16) and 49 and 79 DAE for the second growing season (2016/17), corresponding to the vegetative and reproductive stages of plants, were evaluated. The assessments were taken in the middle third of the upper leaves (completely expanded and with good exposure to the sun), as following: photosynthesis rate $-\mathrm{A}\left(\mu \mathrm{mol} \mathrm{CO} \mathrm{CO}_{2} \mathrm{~m}^{-2}\right)$, transpiration rate $-\mathrm{E}\left(\mathrm{mmol} \mathrm{H}_{2} \mathrm{O}\right.$ $\left.\mathrm{m}^{-2} \mathrm{~s}^{-1}\right)$, stomatal conductance - gs $\left(\mathrm{mol} \mathrm{H}_{2} \mathrm{O} \mathrm{m}^{-2} \mathrm{~s}^{-1}\right)$, internal $\mathrm{CO}_{2}$ concentration - $\mathrm{Ci}(\mathrm{vpm})$ and leaf temperature - Tleaf $\left({ }^{\circ} \mathrm{C}\right)$. The gas exchange measures were determined by the portable infrared gas analyzer (LCpro+, ADC Bioscientific) in the period from 8:00 to 10:00 in the morning. The equipment was set to use concentrations of $370-400 \mathrm{~mol}$ $\mathrm{mol}^{-1} \mathrm{CO}_{2}$ in the air, which is the reference condition used in the IRGA photosynthesis chamber. The photon flux density photosynthetic active (PPFD) used was $1200 \mu \mathrm{mol}$ [quanta] $\mathrm{m}^{-2} \mathrm{~s}^{-1}$. The minimum equilibration time set for performing the reading was 2 minutes.

Samples were taken in the middle third of the first fully expanded leaf (top to base) during the two evaluation periods in the two-year experiment. The equipment was set to use concentrations of $370-400 \mathrm{~mol} \mathrm{~mol}^{-1} \mathrm{CO}_{2}$ in the air, which is the reference condition used in the IRGA photosynthesis chamber. The photon flux density photosynthetic active (PPFD) used was $1200 \mu \mathrm{mol}$ [quanta] $\mathrm{m}^{-2} \mathrm{~s}^{-1}$. The minimum equilibration time set for performing the reading was 2 minutes.

\section{Nutrients in leaves and grains of rice}

Rice leaf samples were collected from the flag leaf at the full blooming stage. Leaves from 50 plants per plot were collected as proposed by Malavolta (2006), washed and then dried under forced-air circulation at $65{ }^{\circ} \mathrm{C}$ for $72 \mathrm{~h}$ before grinding and analyzing the samples for chemical composition. In each plot, one sample of $100 \mathrm{~g}$ of grains was taken for nutrient analyses. In leaves and grains, the concentrations of $\mathrm{N}, \mathrm{P}, \mathrm{K}, \mathrm{Ca}, \mathrm{Mg}, \mathrm{Cu}, \mathrm{Zn}, \mathrm{Fe}$ and $\mathrm{Mn}$ were determined using methods described by Malavolta et al. (1997).

\section{Shoot dry biomass}

Rice shoots of $1.0 \mathrm{~m}$ from one of the rows, in each plot were sampled at the full blooming stage. The shoots were washed in water and then dried in an oven with forced air circulation at $65 \circ \mathrm{C}$, then weighed to determine the shoot dry mass.

\section{Yield components and grain yield}

Rice harvest was carried out by hand after physiological maturity (March $30^{\text {th }}, 2016$ and March 21 ${ }^{\text {st }}, 2017$ ) of the grains in the usable area of each plot. Plots were evaluated for the number of panicles $\mathrm{m}^{-1}$, which was determined by counting the number of panicles within $1.0 \mathrm{~m}$ of one of the rows in the useful area of each plot; number of grains per panicle, which was determined by counting the number of grains in 10 panicles random sampled in the usable area and divided by 10; the mass of 1000 grains, which was randomly evaluated by collecting and weighing 1000 grains from each plot, corrected to $13 \%$ of water content; and the grain yield, which was determined by weighing the harvested grain of each plot, corrected to $13 \%$ of the water content and converted to $\mathrm{kg} \mathrm{ha}^{-1}$.

\section{Statistical analysis}

For the statistical analysis, the SAS Statistical Software, SAS Institute, Cary, NC, USA (SAS, 1999) was used. In the qualitative factor (with or without Serratia spp. strain BRM32114), data was subjected to an analysis of variance, and when the $F$ test proved significant, the data was compared by a Tukey test at $p<0.05$. In the quantitative factor ( $P$ rates), results were submitted to regression analysis when $p<0.05$. The blocks and all block interactions were considered as random effects. The $P$ rates, use of rhizobacteria (Serratia spp. strain BRM32114) and year were considered as fixed effects.

\section{Conclusions}

The trial was conductedto evaluate beneficial microorganism on the development of aerobic rice, under field conditions in tropical region. This is one of the first studies that connected microorganism and $P$ rates in the crop aerobic rice. The results showed that phosphorus rates increased the number of panicles and grain yield of aerobic rice, and the grain yield was higher with Serratia inoculation than without. Under notillage, Serratia spp. strain BRM 32114 was inserted in the production system of aerobic rice and promoted higher gas exchange activity, enriched the $\mathrm{K}, \mathrm{Ca}$ and $\mathrm{Mg}$ content in leaves, enhanced biomass accumulation, and resulted in a higher number of panicles per plant and grain yield than untreated plants. Therefore, this beneficial microorganism is a promising technology for potential incorporation into cropping systems in Brazilian Cerrado region and could be evaluated under different aerobic conditions worldwide.

\section{Acknowledgment}

To the National Council for Scientific and Technological Development (CNPq) for a research award to the first and second author. 


\section{References}

Auge RM (2001) Water relation drought and vesiculararbuscular mycorrhizal symbiosis. Mycorrhiza. 11:3-42.

Alori ET, Glick BR, Babalola OO (2017) Microbial phosphorus solubilization and its potential for use in sustainable agriculture. Front Microbiol. 8:971.

Alvarez RCF, Crusciol CAC, Nascente AS (2014) Aerobicrice yield as a function of growth regulators. Rev Ceres. 61:42-49.

Bandara WMMS, Seneviratne G, Kulasooriya SA (2006) Interaction among endophytic bacteria and fungi: effects and potential. J Biosci. 31:645-650.

Barzana G, Aroca R, Paz JA, Chaumont F, Martinez-Ballest MC, Carvajal M, Ruiz-Lozano JM (2012) Arbuscular mycorhhizal symbiosis increases relative apoplastic water flow in roots of the host plant under both well-watered and drought stress conditions. Ann Bot-London. 109:1009-1017.

Calvo P, Nelson L, Kloepper JW (2014) Agricultural uses of plant biostimulants. Plant Soil. 383:3-41.

Chen YP, Rekha PD, Arun AB, Shen FT, Lai WA, Young CC (2006) Phosphate solubilizing bacteria from subtropical soil and their tricalcium phosphate solubilizing abilities. Appl Soil Ecol. 34:33-41.

Crusciol CAC, Mauad M, Alvarez RCF, Lima EV, Tiritan CS (2005) Phosphorus doses and root growth of aerobic rice. Bragantia. 64:643-649.

Donagema GK, Campos DVB, Calderano SB, Teixeira WG (2011) Manual for Methods of Soil Analysis, 2nd edn. Embrapa Solos, Rio de Janeiro, Brazil.

EMBRAPA (2006) Brazilian System of Soil Classification. 2nd. Embrapa Solos, Rio de Janeiro, Brazil.

Fageria NK (2009) The Use of Nutrients in Crop Plants. Boca Raton, Florida, USA.

Fageria NK, Baligar VC (2003) Aerobicrice and allelopathy. Commu Soil Sci Plant. 34:1311-1329.

Fageria NK, Moraes OP, Vasconcelos MJ (2013) Aerobicrice genotypes evaluation for phosphorus use efficiency. J Plant Nutr. 36:1868-1880.

Fageria NK (1984) Response of rice cultivars to liming in Cerrado soil. Pesqu Agropecu Bras. 19:883-889.

Fageria NK, Moreira A, Coelho AM (2011) Yield and yield components of aerobicrice as influenced by nitrogen sources. J Plant Nutr. 34:361-370.

Fageria NK, Nascente AS (2014) Management of Soil Acidity of South American Soils for Sustainable Crop Production. Adv Agron. 128:221-275.

Fageria NK, Barbosa Filho MP, Carvalho JRP (1982) Response of aerobic rice to phosphorus fertilization on an oxisol of Central Brasil. Agron J. 74:51-56.

Goldstein AH (1986) Bacterial solubilization of mineral phosphates: historical perspective and future prospects. Am J Altern Agric. 1:51-57.

Guo BZ, Chen ZY, Lee RD, Scully BT (2008) Drought stress and preharvest aflatoxin contamination in agricultural commodity: genetics, genomics and proteomics. J Int Plant Biol. 50:12811291.

Heinemann AB, Stone LF (2009) Effect of water deficit on the development and grain yield of four aerobicrice cultivars. Pesqui Agropecu Trop. 39:134-139.

Kado CJ, Heskett MG (1970) Selective media for isolation of Agrobacterium, Corynebacterium, Erwinia, Pseudomonas and Xanthomonas. Phytopathology. 60:969-976.
Krishnaraj PU, Goldstein AH (2001) Cloning of a Serratia marcescens DNA fragment that induces quinoprotein glucose dehydrogenase-mediated gluconic acid production in Escherichia coli in the presence of stationary phase Serratia marcescens. FEMS Microbiol Letters. 205:215 - 220.

Kumar V, Ladha JK (2011) Direct seeding of rice: recent developments and future research needs. Adv Agron. 111:297-396.

Lavakush YJ, Verma JP, Jaiswal KD, Kumar A (2014) Evaluation of PGPR and different concentration of phosphorus level on plant growth, yield and nutrient uptake of rice (Oryza sativa). Ecol Eng. 62:123-128.

Malavolta E, Vitti GC, Oliveira AS (1997) Evaluation of nutritional plant status. Potafós, Piracicaba, SP, Brazil

Malavolta E (2006) Manual of plant nutrition. Agronômica Ceres, São Paulo, Brazil.

Mullins G (2009) Phosphorus, Agriculture and the environment. Virginia Cooperative Extention. College of Agriculture and Life Sciences, Virginia Polytechnic Institute and State University. Publication, 424-029.

Nascente AS, Lacerda MC, Carvalho MCS, Mondo VH (2014) Gypsum and phosphorus in the development of aerobic rice under a no-tillage system. Afr J Agric Res. 9:3645-3654.

Nascente AS, Filippi MCC, Lanna AC, Sousa TP, Souza ACA, Lobo VLS, Silva GB (2017) Effects of beneficial microorganisms on lowland rice development. Environ Sci Pollut Res. 24:2523325242.

Pérez-García A, Romero D, Vicente A (2011) Plant protection and growth stimulation by microorganisms: biotechnological applications of Bacilli in agriculture. Curr Opin Biotechnol. 22:187-193.

Rêgo MCF, Ilkiu-borges F, Filippi MCC, Gonçalves LA, Silva GB (2014) Morphoanatomical and Biochemical Changes in the Roots of Rice Plants Induced by Plant Growth-Promot ing Microorganisms. J Botany. 1-10. doi:10.1155/2014/818797.

Rodriguez H, Fraga R (1999) Phosphate solubilizing bacteria and their role in plant growth promotion. Biotechnol Adv. 17:319339.

Rodriguez H, Gonzalez T, Goire I, Bashan Y (2004) Gluconic acid production and phosphate solubilization by the plant growthpromoting bacterium Azospirillum spp. Naturwissenschaften. 91:552-555.

Sandhu N, Torres RO, Cruz MTS, Maturan PC, Jain R, Kumar A, Henry A (2015) Traits and QTLs for development of dry directseeded rainfed rice varieties. J Exp Botany. 66:225-244.

SAS Institute (1999) Procedure guide for personal computers. Version 5. Sas Institute, Cary.

Sousa DMG, Lobato E (2003) Cerrado: soil correction and fertilization. Embrapa Cerrados, Planaltina, DF, Brazil.

Sudhakara RM, Kumar S, Babita K, Reddy MS (2002) Biosolubilization of poorly soluble rock phosphates by Aspergillus tubingensis and Aspergillus niger. Bioresour Technol. 84:187-189.

Turan M, Ataoglu N, Sahin F (2006) Evaluation of the capacity of phosphate solubilizing bacteria and fungi on different forms of phosphorus in liquid culture. J. Sust Agric. 28:99-108.

Viverk K, Singh KP (2001) Enriching vermicompost by nitrogen fixing and phosphate solubilizing bacteria. Bioresour Technol. 76:173-175.

Zhang G, Zeng Y, Chen M, Yu Z, Yu H, Li Y, Yu H (2011) Huang Effects of physic chemical parameters on the bacterial and fungal communities during agricultural waste composting. Bioresour Technol. 102:2950-2956. 